\title{
Short communication: Screening inhibition of dairy-relevant pathogens and spoilage microorganisms by lactose oxidase
}

\author{
Sofía Lara-Aguilar and Samuel D. Alcaine* \\ Department of Food Science, Cornell University, Ithaca, NY 14853
}

\section{ABSTRACT}

The inhibitory effect of lactose oxidase on the growth of foodborne pathogens and spoilage microorganisms associated with dairy products was evaluated through an overlay inhibition assay. Lactose oxidase generates hydrogen peroxide via lactose oxidation into lactobionic acid. Escherichia coli O157:H7, Listeria monocytogenes, Salmonella enterica ser. Typhimurium, Staphylococcus aureus, Pseudomonas fragi, and Penicillium chrysogenum were used as indicators. A commercially available solution of lactose oxidase was applied at different concentrations $(0,0.12,1.2$, and $12 \mathrm{~g} / \mathrm{L})$ in 4 types of media [brain heart infusion agar (BHI), BHI + sodium thiocyanate (NaSCN), BHI + lactose, and BHI + NaSCN + lactose] to evaluate the effect of lactose and thiocyanate on microbial inhibition. Lactose oxidase inhibited the growth of all the indicators at a concentration of $12 \mathrm{~g} / \mathrm{L}$ of the enzyme solution in the presence of lactose alone and in combination with NaSCN. However, supplementation with NaSCN had no effect on the magnitude of microbial inhibition. Staphylococcus aureus was the most sensitive pathogen, and $P s$. fragi was the most sensitive of all the indicators in general to lactose oxidase. Listeria monocytogenes and Ps. fragi showed higher susceptibility to the antimicrobial effect of lactose oxidase at $6^{\circ} \mathrm{C}$ than at their corresponding optimum growth temperature. The inhibitory effect was attributed to the generation of hydrogen peroxide from the oxidation of lactose. Findings from this study demonstrate that lactose oxidase could be used as a novel approach to inhibit the growth of mold and bacteria. It could also be applied as a label-friendly preservative in dairy foods.

Key words: antimicrobial, enzyme

Received April 5, 2019.

Accepted May 24, 2019.

*Corresponding author: alcaine@cornell.edu

\section{Short Communication}

Foodborne bacterial pathogens cause around 3.6 million illnesses, 35,000 hospitalizations, and 860 deaths in the United States each year (Scallan et al., 2011). Specifically, $18 \%$ of the foodborne illnesses caused by pathogenic bacteria between 1998 and 2008 were attributed to dairy products (Painter et al., 2013). Some of the prevalent pathogens associated with dairy foods are Salmonella spp., Escherichia coli, Listeria monocytogenes, Campylobacter spp., and Staphylococcus aureus ( $\mathrm{Lu}$ and Wang, 2017). The presence of these pathogens in dairy products can be attributable to faulty pasteurization, contaminated processing environment and equipment, and poor hygiene practices of food handlers (Oliver et al., 2005; Schon et al., 2016; Marriott and Gravani, 2017). Examples of pathogenic contamination of dairy products include soft cheese recalls due to Salmonella (Gould et al., 2014), recalls of queso fresco involving Staph. aureus and L. monocytogenes (TorresVitela et al., 2012; Gould et al., 2014), and an outbreak of L. monocytogenes in ice cream (Pouillot et al., 2016).

Contamination by bacterial pathogens is one cause of food loss for the dairy industry, but microbial spoilage is a primary driver of dairy waste (Garnier et al., 2017). More than 10 million tons of dairy products went to waste in 2010, and dairy was the food group with the largest loss at the retail level (Buzby et al., 2014). Common sources of spoilage microflora are raw milk, water, air and surfaces in contact with the product, and brines (Martin et al., 2012; Stellato et al., 2015; Pinto et al., 2018). Psychrotrophic bacteria represent the main cause of spoilage of dairy products, and Pseudomonas spp. is one of the predominant species due to its ability to grow under refrigeration conditions ( $\mathrm{Lu}$ and Wang, 2017). Pseudomonas growth causes off-flavors and offodors due to the production of enzymes that degrade proteins and lipids (Raposo et al., 2017) as well as color changes in the surface of dairy products, such as cheese (Martin et al., 2011).

Molds and yeast are also common causes of spoilage of dairy products such as cheese and yogurt. Molds can grow under acidic conditions in fermented dairy 
products and cause visual surface changes in color, odor, and flavor (Lu and Wang, 2017). Penicillium is the most commonly reported spoilage genus (Garnier et al., 2017), and it has been found in vacuum-sealed cheese stored under refrigeration (Lu and Wang, 2017). It has been reported that some Penicillium strains are resistant to sorbate, a common cheese preservative, and can metabolize it, developing off-odors and off-flavors (Garnier et al., 2017).

The implementation of good manufacturing practices and the application of technologies such as pasteurization, air filtration, and packaging under modified atmospheres has aimed to reduce both spoilage and the number of outbreaks caused by dairy products (Carrascosa et al., 2016). Preservatives such as sorbic acid and benzoic acid have aided the dairy industry in preventing bacteria and mold growth during storage (Herr, 2011). Nevertheless, postprocessing contamination remains an issue for the food industry, and there is a need for technologies to control it (Boor et al., 2017; Garnier et al., 2017). This need is further compounded by the increasing consumer demand for clean labels and "natural" products, challenging the industry to explore alternative options.

Enzyme-based preservation technologies represent a clean-label approach to preserving dairy foods (DelvesBroughton, 2012). A consensus definition of what specifically constitutes clean-label ingredients can be difficult to reach and is influenced by food category and ingredient positioning (Asioli et al., 2017). Consumer awareness of natural antimicrobials versus chemical preservatives is growing, and naturally occurring antimicrobial enzymes fall within the former category (Carocho et al., 2015). Dairy consumers in particular may be primed to see enzymes as natural components of food because enzymes are commonly found on dairy food labels. Microbial-produced enzymes such as rennet are used as a milk coagulation in many cheeses (Ben Amira et al., 2017), enzymes are listed for cheese ripening and flavor development (Kilcawley et al., 2012), and the enzyme lactase is regularly used in the produc- tion of lactose-free milk (Harju et al., 2012). Lactose oxidase (LO) is natural, microbial-derived enzyme with potential application as a natural antimicrobial in dairy foods. Lactose oxidase generates hydrogen peroxide, a well-known antimicrobial compound, as a product of the oxidation of lactose to lactobionic acid (Nordkvist et al., 2007). Hydrogen peroxide has proven to be an effective antimicrobial in foods such as leafy greens (Moore et al., 2011), milk (Martin et al., 2014; Kozak et al., 2018b), and queso fresco (Kozak et al., 2018a), among others. However, the direct addition of hydrogen peroxide is not aligned with current consumer trends and is not always feasible (due to rapid dissipation) or permitted, depending on the product (Martin et al., 2014; Kozak et al., 2018b). Thus, LO represents a natural means to provide antimicrobial control.

In a previous study by Lara-Aguilar and Alcaine (2019), LO showed a bactericidal effect against Pseudomonas fragi in milk and a synergistic effect with thiocyanate $\left(\mathrm{SCN}^{-}\right)$. However, its antimicrobial activity against foodborne pathogens and other spoilage microorganisms such as molds has not been investigated. The objective of this study was to screen the antimicrobial effect of LO against pathogens and spoilage microorganisms associated with milk and dairy products.

Four foodborne pathogens, 1 spoilage bacterium, and 1 mold (Table 1) were used to determine the antimicrobial activity of LO (LactoYield, Chr. Hansen, Milwaukee, WI) in different media. For all the bacterial strains, a frozen culture was streaked onto brain heart infusion agar (BHI; Difco, BD Diagnostics, Franklin Lakes, NJ) and incubated for $24 \mathrm{~h}$ at $37^{\circ} \mathrm{C}$ for pathogens and $32^{\circ} \mathrm{C}$ for Ps. fragi. An individual colony was then used to inoculate $5 \mathrm{~mL}$ of BHI broth, followed by $18 \mathrm{~h}$ of incubation at the same temperatures previously mentioned. The mold was spot plated onto malt extract agar (Difco, BD Diagnostics) and incubated at $25^{\circ} \mathrm{C}$ for 4 wk. Spore formation was confirmed by microscopy. Spores were harvested by adding sterile water with $0.1 \%$ Tween 80 (Baker Analyzed, Philipsburg, NJ) to the plate and scraping the wet surface with a sterile

Table 1. Classification and incubation temperatures of the microorganisms used as indicators in the overlay inhibition assay

\begin{tabular}{lll}
\hline Microorganism & Classification & $\begin{array}{l}\text { Incubation } \\
\text { temperature }\left({ }^{\circ} \mathrm{C}\right)\end{array}$ \\
\hline $\begin{array}{l}\text { Escherichia coli } \text { O157:H7 (ATCC 43889) } \\
\text { Listeria monocytogenes }\end{array}$ & Pathogenic & 37 \\
Salmonella enterica ser. Typhimurium $_{\text {Staphylococcus aureus }(\text { ATCC } 8095)^{1}}$ & Pathogenic & 6 and 37 \\
Pseudomonas fragi $^{2}$ & Pathogenic & 37 \\
Penicillium chrysogenum $^{1}$ & Pathogenic & 37 \\
\hline
\end{tabular}

${ }^{1}$ Isolate from the Food Safety Laboratory, Cornell University, Ithaca, NY.

${ }^{2}$ Isolate from the collection of Randy Worobo, Cornell University, Geneva, NY. 
spreader. The spores and mycelia were filtered through sterile cheesecloth into a sterile bottle to isolate spores only. The suspensions were combined with glycerol at $50 \%$ ( $\mathrm{vol} / \mathrm{vol}$ ) and stored at $-80 \pm 2^{\circ} \mathrm{C}$ until use.

Four types of media were used to test the inhibitory effect of LO: BHI, BHI supplemented with sodium thiocyanate (NaSCN; $14 \mathrm{mg} / \mathrm{L})$, BHI supplemented with lactose (2.5\% mass/vol), and BHI supplemented with both NaSCN (14 mg/L) and lactose (2.5\% mass/vol). The NaSCN and lactose were added to the media after sterilization in a solution previously filter-sterilized through a surfactant-free cellulose acetate membrane with $0.20-\mu \mathrm{m}$ pore size. The well diffusion method described by Ahn and Stiles (1990) was followed to test the antimicrobial effect of 4 concentrations $(0,0.12,1.2$, and $12 \mathrm{~g} / \mathrm{L}$ ) of the LO solution. Wells (8-mm diameter) cut into each type of media were filled with $100 \mu \mathrm{L}$ of enzyme solution and allowed to diffuse into the agar in a laminar flow hood. Once the solution had been completely absorbed, a $5-\mu \mathrm{L}$ aliquot of catalase (Sigma Aldrich, St. Louis, MO) was spotted next to the well to determine whether the antimicrobial effect was caused by hydrogen peroxide. Plates were overlaid with a 10$\mathrm{mL}$ aliquot of $0.75 \%$ agar inoculated with $100 \mu \mathrm{L}$ of $18-\mathrm{h}$ culture for bacteria or spore suspension. Plates were incubated for $24 \mathrm{~h}$ at $37^{\circ} \mathrm{C}$ for all the pathogens and at $32^{\circ} \mathrm{C}$ for Ps. fragi. For the mold, plates were incubated for $3 \mathrm{~d}$ at $25^{\circ} \mathrm{C}$. A study at $6^{\circ} \mathrm{C}$ was performed for $L$. monocytogenes and Ps. fragi because of their ability to grow under refrigerated conditions. The refrigerated plates were incubated until there was enough growth to see the inhibition zones, which took between 3 and 6 d, depending on the microorganism. For Ps. fragi, the assay was replicated using Luria-Bertani agar (Difco, BD Diagnostics). The antimicrobial activity was determined by measuring the width of the inhibition zone. Three perpendicular measurements of the diameter per well were used to calculate the average inhibition diameter for each treatment. Assays were carried out in duplicate and repeated 3 independent times.

The antimicrobial activity of an LO solution was evaluated by applying increasing concentrations of the enzyme on media with different composition to evaluate the effect of lactose and $\mathrm{SCN}^{-}$on microbial growth inhibition. All the indicators were inhibited when the LO solution was applied at a concentration of $12 \mathrm{~g} / \mathrm{L}$ in the presence of lactose alone and combined with NaSCN (Table 2). Among the pathogens, Staph. aureus was found to be the most sensitive because it was the only species in the study that was inhibited at a concentration of $1.2 \mathrm{~g} / \mathrm{L}$ of LO solution under optimal growth conditions. This sensitivity to hydrogen peroxide is consistent with other research showing that Staph. aureus can also be inhibited by hydrogen per- oxide produced by competitive bacteria (Dahiya and Speck, 1968; Regev-Yochay et al., 2006). Lactose oxidase also showed inhibition of Penicillium chrysogenum growth in both media containing lactose. Other studies have reported antifungal activity of hydrogen peroxide against food spoilage molds such as Penicillium expansum (Venturini et al., 2002) and Penicillium digitatum (Cerioni et al., 2009).

To confirm that the generation of $\mathrm{H}_{2} \mathrm{O}_{2}$ was the cause of the antimicrobial activity, catalase was spotted next to the well to remove the compound where the inhibition zone would be formed. Results showed microbial growth on the area where the catalase was located for all the indicators. Based on these observations, it was concluded that the antimicrobial activity was attributed to the production of $\mathrm{H}_{2} \mathrm{O}_{2}$ as a product of lactose oxidation by LO. Other studies have attributed an antimicrobial effect to the production of hydrogen peroxide by lactobacilli (Price and Lee, 1970; Collins and Aramaki, 1980) and glucose oxidase present in honey (Mundo et al., 2004).

Except for Ps. fragi, none of the microorganisms in this study were inhibited on the control or the NaSCNsupplemented media at any level of LO, showing that the antimicrobial effect is mainly caused by the production of $\mathrm{H}_{2} \mathrm{O}_{2}$ in situ due to the oxidation of lactose and not by any of the components of the enzymatic solution. Furthermore, the addition of NaSCN had no influence on the antimicrobial effect of LO with lactose (Table 2). This result contrasts with our previous results obtained in milk, where $\mathrm{SCN}^{-}$enhanced the antimicrobial activity of LO against Ps. fragi even in the absence of lactoperoxidase (Lara-Aguilar and Alcaine, 2019). This difference may be attributable to differences in the distribution of the LO (homogeneous in the milk vs. diffusion in the agar) and the differences in the application and level of the bacterial load between the 2 studies.

Both Ps. fragi and L. monocytogenes showed higher sensitivity to the antimicrobial effect of $\mathrm{LO}$ at $6^{\circ} \mathrm{C}$ than at their optimum growth temperature. Listeria monocytogenes was inhibited at a lower enzyme concentration $(1.2 \mathrm{~g} / \mathrm{L})$, and the zone of inhibition at 12 $\mathrm{g} / \mathrm{L}$ tripled. Pseudomonas fragi was inhibited at the lowest concentration of $\mathrm{LO}$ solution $(0.12 \mathrm{~g} / \mathrm{L})$. The increase in the sensitivity to $\mathrm{LO}$ at lower temperature of both these organisms may be driven by differences in gene expression or membrane composition. Studies in L. monocytogenes have shown that temperature can change susceptibility to various antimicrobials such as nisin ( $\mathrm{Li}$ et al., 2002) and bacteriophage (Tokman et al., 2016). These findings are promising for applications of $\mathrm{LO}$ as a preservative in refrigerated products because Ps. fragi and L. monocytogenes have the abil- 
ity to grow at low temperatures and are one of the main causes of food spoilage (Ledenbach and Marshall, 2009) and outbreaks (Gould et al., 2014). Indeed, in our previous study of Ps. fragi inhibition by LO milk, we observed improved inhibition at refrigeration temperatures (Lara-Aguilar and Alcaine, 2019). Further research is needed to elucidate the mechanisms behind the observed increase in sensitivity in both Ps. fragi and L. monocytogenes to $\mathrm{LO}$ at lower temperatures and whether they are related to membrane composition or changes in gene expression.

As mentioned above, Ps. fragi was the only indicator inhibited on the control (BHI agar) and on NaSCNsupplemented media. Because bacterial growth was observed in the area where the catalase was spotted, the inhibition could potentially be attributed to the $\mathrm{H}_{2} \mathrm{O}_{2}$ produced from the oxidation of glucose, one of the components of BHI agar. Even though LO has high specificity for lactose as substrate, it is also able to oxidase other saccharides such as glucose, galactose, maltose, and cellobiose (Nordkvist et al., 2007). To confirm this effect, the overlay inhibition assay was replicated using Luria-Bertani agar because it does not contain any of those saccharides and thus would preclude $\mathrm{H}_{2} \mathrm{O}_{2}$ production. On this media, Ps. fragi was not inhibited at any level of LO, thus supporting the conclusion that $\mathrm{H}_{2} \mathrm{O}_{2}$ production from the oxidation of glucose by $\mathrm{LO}$ was the source of the inhibition observed in absence of lactose. Although these results indicate that $\mathrm{H}_{2} \mathrm{O}_{2}$ must have been produced from glucose in all of the control plates, the amount produced was not sufficient to have an observable inhibitory effect on the other microorganism we screened (Table 2), and Pseudomonas spp. is known to be sensitive to $\mathrm{H}_{2} \mathrm{O}_{2}$ (Price and Lee, 1970).

The broad antimicrobial activity of LO against foodborne pathogens and spoilage mold and bacteria, even under refrigerated conditions, suggests that LO could be applied as a novel food preservative in dairy products. Glucose oxidase, which generates $\mathrm{H}_{2} \mathrm{O}_{2}$ from glucose, represents a model for these type of future applications. Glucose oxidase has been shown to be an effective bacterial control agent in a variety of foods and consumer goods such as meat (Tiina and Sandholm, 1989), fish (Field et al., 1986), eggs (Dobbenie et al., 1995), and

Table 2. Zone of inhibition ( $\mathrm{mm} \pm \mathrm{SD} ; \mathrm{n}=3$ ) of growth of foodborne pathogens and spoilage microorganisms by lactose oxidase on brain heart infusion (BHI) agar with different supplementations

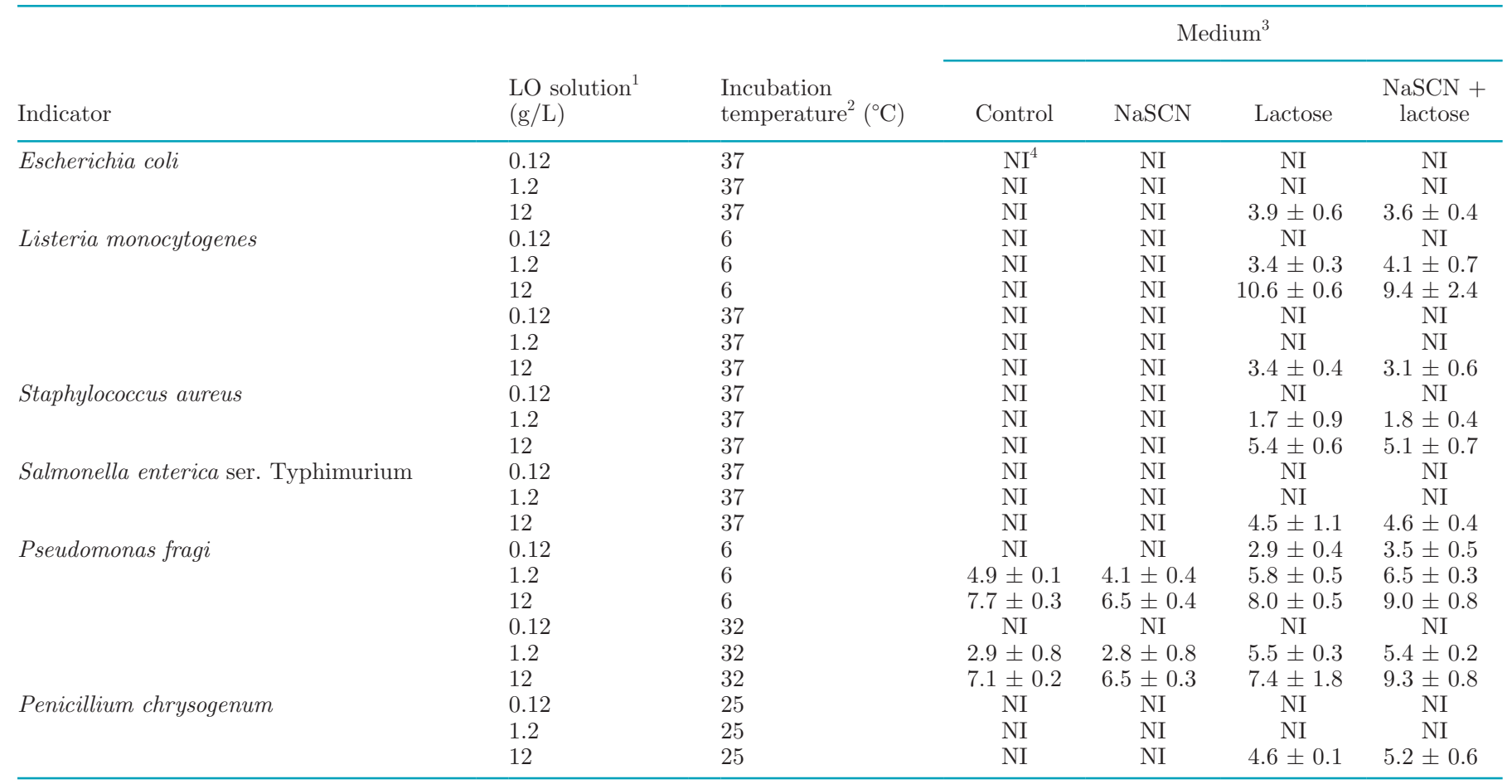

${ }^{1}$ Wells of 8 -mm diameter were cut in the agar plates and filled with $100 \mu \mathrm{L}$ of the lactose oxidase (LO) solution. Plates were overlaid with a 10 -mL aliquot of $0.75 \%$ agar inoculated with $100 \mu \mathrm{L}$ of 18 -h culture for bacteria or spore suspension.

${ }^{2}$ Plates were incubated for $24 \mathrm{~h}$ for all bacteria, except when performed at $6^{\circ} \mathrm{C}$, in which case plates were incubated until there was sufficient growth to see the inhibition zones, which took between 3 and $6 \mathrm{~d}$ depending on the microorganism. For P. chrysogenum, plates were incubated for $3 \mathrm{~d}$.

${ }^{3}$ Control was BHI agar, which was supplemented with sodium thiocyanate (NaSCN) at $14 \mathrm{mg} / \mathrm{L}$, lactose at 2.5\% (mass/vol), or both.

${ }^{4}$ No inhibition. 
wine and toothpaste (Bankar et al., 2009). Glucose oxidase has also been used in dairy systems as an oxygen scavenger and protectant for probiotic cultures in yogurt (Batista et al., 2015). Lactose oxidase could serve similar functions in dairy products utilizing lactose rather than added glucose, though further investigation is required to determine how well the antimicrobial effects of LO translate to dairy matrices with varying levels of residual lactose. It will also be necessary to assess the effect of LO on the sensory properties of the product. Our previous research showed that prolonged contact with LO resulted in significant $\mathrm{pH}$ decreases in fluid milk (Lara-Aguilar and Alcaine, 2019), though there may be less of a sensory effect in low-pH dairy products, topical or spray applications, or applications in which the LO can be removed or inactivated. Overall, our results suggest diverse opportunities for more research on the application of LO for the control of microbial constituents in dairy foods.

\section{ACKNOWLEDGMENTS}

The authors acknowledge the support of the New York State Milk Promotion Advisory Board (Albany, NY) via the New York State Department of Agriculture and Markets (Albany, NY).

\section{REFERENCES}

Ahn, C., and M. E. Stiles. 1990. Antibacterial activity of lactic acid bacteria isolated from vacuum-packaged meats. J. Appl. Bacteriol. 69:302-310.

Asioli, D., J. Aschemann-Witzel, V. Caputo, R. Vecchio, A. Annunziata, T. Naes, and P. Varela. 2017. Making sense of the "clean label" trends: A review of consumer food choice behavior and discussion of industry implications. Food Res. Int. 99:58-71.

Bankar, S. B., M. V. Bule, R. S. Singhal, and L. Ananthanarayan. 2009. Glucose oxidase - An overview. Biotechnol. Adv. 27:489-501.

Batista, A. L. D., R. Silva, L. P. Cappato, C. N. Almada, R. K. A. Garcia, M. C. Silva, R. S. L. Raices, D. B. Arellano, A. S. Sant'Ana, C. A. Conte, M. Q. Freitas, and A. G. Cruz. 2015. Quality parameters of probiotic yogurt added to glucose oxidase compared to commercial products through microbiological, physical-chemical and metabolic activity analyses. Food Res. Int. 77:627-635.

Ben Amira, A., S. Besbes, H. Attia, and C. Blecker. 2017. Milk-clotting properties of plant rennets and their enzymatic, rheological, and sensory role in cheese making: A review. Int. J. Food Prop. 20:S76-S93.

Boor, K. J., M. Wiedmann, S. Murphy, and S. Alcaine. 2017. A 100year review: Microbiology and safety of milk handling. J. Dairy Sci. 100:9933-9951.

Buzby, J. C., H. F. Wells, and J. Aulakh. 2014. Food loss-Questions about the amount and causes still remain. Accessed Jun. 24, 2019. https://www.ers.usda.gov/amber-waves/2014/june/food -loss-questions-about-the-amount-and-causes-still-remain/.

Carocho, M., P. Morales, and I. C. Ferreira. 2015. Natural food additives: Quo vadis? Trends Food Sci. Technol. 45:284-295.

Carrascosa, C., R. Millan, P. Saavedra, J. R. Jaber, A. Raposo, and E. Sanjuan. 2016. Identification of the risk factors associated with cheese production to implement the hazard analysis and critical control points (HACCP) system on cheese farms. J. Dairy Sci. 99:2606-2616.
Cerioni, L., V. A. Rapisarda, M. Hilal, F. E. Prado, and L. RodríguezMontelongo. 2009. Synergistic antifungal activity of sodium hypochlorite, hydrogen peroxide, and cupric sulfate against Penicillium digitatum. J. Food Prot. 72:1660-1665.

Collins, E. B., and K. Aramaki. 1980. Production of hydrogen peroxide by Lactobacillus acidophilus. J. Dairy Sci. 63:353-357.

Dahiya, R. S., and M. L. Speck. 1968. Hydrogen peroxide formation by lactobacilli and its effect on Staphylococcus aureus. J. Dairy Sci. 51:1568-1572.

Delves-Broughton, J. 2012. Natural antimicrobials as additives and ingredients for the preservation of foods and beverages. Pages 127-161 in Natural Food Additives, Ingredients and Flavourings. D. Baines and R. Seal, ed. Woodhead, Sawston, UK.

Dobbenie, D., M. Uyttendaele, and J. Debevere. 1995. Antibacterial activity of the glucose-oxidase glucose system in liquid whole egg. J. Food Prot. 58:273-279.

Field, C. E., L. F. Pivarnik, S. M. Barnett, and A. G. Rand. 1986. Utilization of glucose-oxidase for extending the shelf-life of fish. J. Food Sci. 51:66-70.

Garnier, L., F. Valence, and J. Mounier. 2017. Diversity and control of spoilage fungi in dairy products: An update. Microorganisms 5:E42.

Gould, L. H., E. Mungai, and C. B. Behravesh. 2014. Outbreaks attributed to cheese: Differences between outbreaks caused by unpasteurized and pasteurized dairy products, United States, 1998 2011. Foodborne Pathog. Dis. 11:545-551.

Harju, M., H. Kallioinen, and O. Tossavainen. 2012. Lactose hydrolysis and other conversions in dairy products: Technological aspects. Int. Dairy J. 22:104-109.

Herr, B. 2011. Additives in dairy foods: Types and functions of additives in dairy products. Pages $34-40$ in Encyclopedia of Dairy Sciences. 2nd ed. J. W. Fuquay, P. F. Fox, and P. L. H. McSweeney, ed. Elsevier, Oxford, UK.

Kilcawley, K. N., A. B. Nongonierma, J. A. Hannon, I. A. Doolan, and M. G. Wilkinson. 2012. Evaluation of commercial enzyme systems to accelerate Cheddar cheese ripening. Int. Dairy J. 26:50-57.

Kozak, S. M., Y. Bobak, and D. J. D'Amico. 2018a. Efficacy of antimicrobials applied individually and in combination for controlling Listeria monocytogenes as surface contaminants on queso fresco. J. Food Prot. 81:46-53.

Kozak, S. M., S. Brown, Y. Bobak, and D. J. D'Amico. 2018b. Control of Listeria monocytogenes in whole milk using antimicrobials applied individually and in combination. J. Dairy Sci. 101:1889-1900.

Lara-Aguilar, S., and S. D. Alcaine. 2019. Lactose oxidase: A novel activator of the lactoperoxidase system in milk for improved shelf life. J. Dairy Sci. 102:1933-1942.

Ledenbach, L. H., and R. T. Marshall. 2009. Microbiological spoilage of dairy products. Pages 41-67 in Compendium of the Microbiological Spoilage of Foods and Beverages. W. H. Sperber and M. P. Doyle, ed. Springer, New York, NY.

Li, J., M. L. Chikindas, R. D. Ludescher, and T. J. Montville. 2002. Temperature- and surfactant-induced membrane modifications that alter Listeria monocytogenes nisin sensitivity by different mechanisms. Appl. Environ. Microbiol. 68:5904-5910.

Lu, M., and N. S. Wang. 2017. Spoilage of milk and dairy products. Pages 151-178 in The Microbiological Quality of Food: Foodborne Spoilers. A. Beviacqua, M. R. Corbo, and M. Sinigaglia, ed. Woodhead, Sawston, UK.

Marriott, N. G., and R. B. Gravani. 2017. Principles of Food Sanitation. Springer Science + Business Media, New York, NY.

Martin, N. H., A. Friedlander, A. Mok, D. Kent, M. Wiedmann, and K. Boor. 2014. Peroxide test strips detect added hydrogen peroxide in raw milk at levels affecting bacterial load. J. Food Prot. $77: 1809-1813$.

Martin, N. H., N. R. Carey, S. C. Murphy, M. Wiedmann, and K. J. Boor. 2012. A decade of improvement: New York State fluid milk quality. J. Dairy Sci. 95:7384-7390.

Martin, N. H., S. C. Murphy, R. D. Ralyea, M. Wiedmann, and K. J. Boor. 2011. When cheese gets the blues: Pseudomonas fluorescens as the causative agent of cheese spoilage. J. Dairy Sci 94:3176-3183. 
Moore, K. L., J. Patel, D. Jaroni, M. Friedman, and S. Ravishankar. 2011. Antimicrobial activity of apple, hibiscus, olive, and hydrogen peroxide formulations against Salmonella enterica on organic leafy greens. J. Food Prot. 74:1676-1683.

Mundo, M. A., O. I. Padilla-Zakour, and R. W. Worobo. 2004. Growth inhibition of foodborne pathogens and food spoilage organisms by select raw honeys. Int. J. Food Microbiol. 97:1-8.

Nordkvist, M., P. M. Nielsen, and J. Villadsen. 2007. Oxidation of lactose to lactobionic acid by a Microdochium nivale carbohydrate oxidase: Kinetics and operational stability. Biotechnol. Bioeng. 97:694-707.

Oliver, S. P., B. M. Jayarao, and R. A. Almeida. 2005. Foodborne pathogens in milk and the dairy farm environment: Food safety and public health implications. Foodborne Pathog. Dis. 2:115-129.

Painter, J. A., R. M. Hoekstra, T. Ayers, R. V. Tauxe, C. R. Braden, F. J. Angulo, and P. M. Griffin. 2013. Attribution of foodborne illnesses, hospitalizations, and deaths to food commodities by using outbreak data, United States, 1998-2008. Emerg. Infect. Dis. 19:407-415.

Pinto, C. L. O., L. V. Souza, V. A. S. Meloni, C. S. Batista, R. Silva, E. M. F. Martins, A. G. Cruz, and M. L. Martins. 2018. Microbiological quality of Brazilian UHT milk: Identification and spoilage potential of spore-forming bacteria. Int. J. Dairy Technol. 71:20-26.

Pouillot, R., K. C. Klontz, Y. Chen, L. S. Burall, D. Macarisin, M. Doyle, K. M. Bally, E. Strain, A. R. Datta, T. S. Hammack, and J. M. Van Doren. 2016. Infectious dose of Listeria monocytogenes in outbreak linked to ice cream, United States, 2015. Emerg. Infect. Dis. 22:2113-2119.

Price, R. J., and J. S. Lee. 1970. Inhibition of Pseudomonas species by hydrogen peroxide producing lactobacilli. J. Milk Food Technol. $33: 13-18$.

Raposo, A., E. Pérez, C. T. de Faria, M. A. Ferrús, and C. Carrascosa. 2017. Food spoilage by Pseudomonas spp.-An overview. Pages
41-74 in Food Borne Pathogens and Antibiotic Resistance. O. V. Singh, ed. Wiley, Hoboken, NJ.

Regev-Yochay, G., K. Trzcinski, C. M. Thompson, R. Malley, and M. Lipsitch. 2006. Interference between Streptococcus pneumoniae and Staphylococcus aureus: In vitro hydrogen peroxide-mediated killing by Streptococcus pneumoniae. J. Bacteriol. 188:4996-5001.

Scallan, E., R. M. Hoekstra, F. J. Angulo, R. V. Tauxe, M. A. Widdowson, S. L. Roy, J. L. Jones, and P. M. Griffin. 2011. Foodborne illness acquired in the United States-Major pathogens. Emerg. Infect. Dis. 17:7-15.

Schon, K., E. Schornsteiner, M. Dzieciol, M. Wagner, M. Muller, and S. Schmitz-Esser. 2016. Microbial communities in dairy processing environment floor-drains are dominated by product-associated bacteria and yeasts. Food Control 70:210-215.

Stellato, G., F. De Filippis, A. La Storia, and D. Ercolini. 2015. Coexistence of lactic acid bacteria and potential spoilage microbiota in a dairy processing environment. Appl. Environ. Microbiol 81:7893-7904

Tiina, M., and M. Sandholm. 1989. Antibacterial effect of the glucose oxidase-glucose system on food-poisoning organisms. Int. J. Food Microbiol. 8:165-174.

Tokman, J. I., D. J. Kent, M. Wiedmann, and T. Denes. 2016. Temperature significantly affects the plaquing and adsorption efficiencies of Listeria phages. Front. Microbiol. 7:631.

Torres-Vitela, M. R., M. Mendoza-Bernardo, J. Castro-Rosas, C. A. Gomez-Aldapa, L. E. Garay-Martinez, V. Navarro-Hidalgo, and A. Villarruel-Lopez. 2012. Incidence of Salmonella, Listeria monocytogenes, Escherichia coli O157:H7, and staphylococcal enterotoxin in two types of Mexican fresh cheeses. J. Food Prot. 75:79-84.

Venturini, M. E., D. Blanco, and R. Oria. 2002. In vitro antifungal activity of several antimicrobial compounds against Penicillium expansum. J. Food Prot. 65:834-839. 